\title{
Representation of Women in Popular Indian Movies : An Analysis of English Vinglish and Heroine
}

\author{
Anju Ok \\ Research Scholar \\ Department of English \\ Pondicherry University \\ Pondicherry, India \\ anjuok175@gmail.com
}

\begin{abstract}
Male supremacy and patriarchy has become two clichéd words, but it is a fact that these two words define almost all societies in the world. Indian society is no different from this, in fact this is where these two words fit in smoothly. This is reflected in our literature, art and movies too. My enquiry here is about how do the preconceived notions about feminity find their way into popular movies. The article analyzes two popular Hindi movies: English Vinglish and Heroine. These two movies portray two women who are very different from each other ; a house wife and an actress. But many a times these two women are one and the same in terms of the attitude of the society towards them. Therefore the paper intends to reveal the double standards and hypocrisy of Indian society.

Keywords: Popular Cinema, Patriarchy, Representation, Control

Introduction
\end{abstract}

Cinema is regarded as the common man's medium of information and entertainment. Cinema and culture is interdependent ; culture shapes cinema and cinema shapes culture. In other words, "Cinema is the medium of culture" (Bharti). There is no debate in the fact that 
the society we live in, the Indian society, is patriarchal. Therefore it is this patriarchal culture that is disseminated through the medium of cinema. One of the main goals of feminism is to examine how women are represented in literature and visual media. It had started right from Kate Millet's Sexual Politics in which she harshly criticizes the biased portrayal of women in the works of D H Lawrence, Norman Mailer and Henry Miller. Cinema being a more popular media, it is important to see how women are represented, and how women related issues are addressed. For this purpose we should have a different 'eye'; a feminist eye with which we should approach movies. Normal 'eye' is so conditioned by patriarchy that it perceives the heavily biased media representations as something very natural. The distinction is invisible so that it passes through the normal eye without being detected. This paper is an enquiry about the how are women in movies shaped. I have selected two bollywood movies : English Vinglish and Heroine for this enquiry. True that bollywood does not define India cinema, but being the most popular film industry in India it cannot be denied it has a vast access in and out India. Let us look into how these two apparently different movies eventually converge at a point.

Discussion

English Vinglish is a movie by Gauri Shinde ;a movie about a woman by a woman. The lead character of the movie Shashi Godbole is the perfect house wife; the ideal wife, the ever-caring mother, the dutiful daughter in law and a small entrepreneur. This can be inferred from the first scene where she places back her coffee mug repeatedly to fulfill all other requirements. Her only handicap is English for which she frequently receives taunts from her husband and daughter. She is the normal 'taken for granted' female who is not expected to have a desire for respect and companionship but only to fulfil her wifely duties. The question " agar mein khana acha nahi banathi tho thum ghar hi nahi aathi ,he na?" 'If I don't cook well, you would not bother coming back home,right?' ( my trans.; English Vinglish) sums up 
Shashi's disappointment. Her daughter, another female, but different from Shashi in terms of her confidence and proficiency in English, is too young to understand her mother's emotions and often mocks her incompetency in English; "thum padaogi mujhe English literature?" 'Oh, will you teach me English literature?'(my trans.; English Vinglish). Shashi, like many Indian house wives, is constantly concerned about pleasing others but is let down by the educated strata of the family so that she says " kitni bhi kosish karu, kisiko khush nai kar pathi" "It doesn't matter how hard I try, I cannot make anyone happy' (my trans.; Enlish Vinglish). Her life would have moved on just like that if she had not been invited to us for her niece's wedding in New York. There she meets new challenges resulting from her ignorance. For the first time in her life she takes a decision of her own; to learn English. She could pursue it only because of her small savings from her ladoo business which was mocked by her family. There she meets Laurent who boosts her self esteem calling her an 'artist'; the only person who considers her worthy of respect. Respect is one word which all women deserve in their lives, Shashi too, as she says "mujhe pyar ki zaroorath nahi he ,zaroorat he tho sirf thodi izzath ki" 'I don't need love, what I need is a little respect' (my trans.' English Vinglish) The husband, who arrives late, is not pleased with her independence. The climax of the movie in which she delivers a speech in English in front of all the wedding guests is actually the first time she stands up for her dignity. She righty says "marriage is the friendship of two people who are equals" (English Vinglish) but the friendship seems to be absent in her life. Gauri Shinde might have intended to portray reality with a message to stand up for oneself. But the image here is also stereotypical, for Shashi does not once fall short of the expectations of her family.

Heroine, directed by Madhur Bhandarkar, is a movie about the movie industry. Maahi Arora, the female lead of the movie is the most sought after actress of the industry. Her schizophrenic and bipolar nature is duly supported by a broken family and lonely child 
backdrop. Her professional success is undervalued regarding her personal insecurities. The fact that she does not know to manipulate people lands her in a worthless relationship with superstar Aryan who does not find her worthy to be treated well. But she clings onto him more fiercely each time he behaves like an insensitive tyrant. This is evident in Maahi's words "thum chahe mujhe kitni bhi buri tharah treat kare mein thujhe kabhi embarrass nahi karungy" 'even if you treat me in the worst way possible, I will not embarrass you' (my trans.; Heroine 40:49-40:58). She is even pushed out of a moving car by him. Aryan is the example of the typical contolling and manipulative men who uses women as their property. Her new boyfriend Angad Paul, though appears to be supportive and positive in the beginning turns out to be another disastrous decision She is also seen reduced to a showpiece in her new movie because of her refusal to yield to the desires of her co-star. Maahi's desperate attempt to prove her talent is also crushed into pieces when the film for which she dedicated six months to was cancelled by its director. Added to this is Angad's withdrawal and abuse; "thum logom ko pyar nahi kar sakthe he, sirf isthemal kar sakthe he" 'you cannot be loved, but only be used' (my trans.; Heroine). Her patch up with Aryan ends disastrously and she resorts to an extreme measure, to publish her own sex tape , for her film's success. But this lands her in complete misery from which she escapes to a far away land where no one recognizes her. The movie was supposed to be women centric, but it turns out to be just another patriarchal controlling of a woman character.

The Point of Convergence.

The ideal house wife and the typical actress are not very different from each other. Shashi or Maahi, it is a woman inside the package. The socially accepted supremacy and subordination of men and women respectively is evident in both movies. Shashi is the dream wife of every 'man'; the timid and submissive women entitled to make him' happy. She should always be dependent. She is allowed to learn English but never once can forget her 
duties. Learning English sure empowers Shashi, but problem is when that is celebrated as the reason to start respecting her. Maahi whereas, is the fascination of every 'man'; beautiful and rich .But actresses should always stand a step lower than "actors'. They cannot lead a movie but only supplement to the progress of the story. They cannot assert their presence but only add glitter and sparkle. Maahi looses everything, even her sanity, in her attempt to prove herself in a world controlled by men. The actor, husband and boyfriend here are all men. They draw lines out of which women dare not step. They posses 'their women' and women should please them. Now, coming to economic independence, Shashi is a dependent woman and Maahi an independent woman, but it really does not matter when it comes to attitude towards them.

\section{Conclusion}

Maahi and Shashi are not two characters but two sides of the same coin. The close scrutiny of the movies leads to a conclusion that however independent, worthy or competent a woman is she always presented to be be ready to fit in a patriarchal case. Her desires and self esteem should never grow out of it because then it will disturb men from their convenient slumber. It is difficult to let go the privileges enjoyed for ages. So women should be just women, a private possession not an equal individual. 


\section{Works Consulted}

English Vinglish. Directed by Gauri Shinde, performance by Sridevi, Eros International, 2012.

Heroine. Directed by Madhur Bhandarkar, performance by Kareena Kapoor, UTV Motion Pictures, 2012.

Bharti, Divya. "Cinema of Culture." Times of India, 2020. https://timesofindia.indiatimes.com/readersblog/thinkupon/cinema-of-culture-23928/. Sarkar, Srijita. "An Analysis of Hindi Women-Centric Films in India." Sociology, University of Louisville, 2012. https://ir.library.louisville.edu/etd/1265/.

Tere, Nidhi Shendurnikar. "Gender Reflections in Mainstream Hindi Cinema." Global Media Journal vol. 3, no. 1, 2012, https://www.caluniv.ac.in/global-mdiajournal/Students\%27\%20Research/SR4\%20NIDHI.pdf. 